\title{
HUBUNGAN WORD OF MOUTH TERHADAP BRAND IMAGE, BRAND LOYALTY, BRAND PREFERENCE DAN BRAND LEADERSHIP PELANGAN MEREK MINISO DI JAKARTA BARAT
}

\author{
IRMA SATYA INDRIYANTI \\ KRISTIN NATALIA \\ Trisakti School of Management, JI. Kyai Tapa No. 20, Jakarta 11440, Indonesia \\ satyairma@gmail.com
}

\begin{abstract}
The purpose of this study was to determine the relationship of word of mouth with brand image, brand loyalty, brand preference and brand leadership of Miniso customers in West Jakarta. The sampling used in this study is nonprobability sampling with a purposive sampling method and will require 116 respondents. Only certain samples that meet the criteria and can be used as samples. For this study, the SPSS program is used to determine the effect of all the independent variables above on the dependent variable. The statistical method in this study is multiple regression. Research shows that word of mouth for brand image, brand loyalty, brand preference and brand leadership of Miniso customers in West Jakarta.
\end{abstract}

Keywords: Brand image, brand loyalty, brand preference, brand leadership, word of mouth

Abstrak: Tujuan penelitian adalah untuk mengetahui hubungan word of mouth dengan citra merek, loyalitas merek, preferensi merek dan kepemimpinan merek pelanggan Miniso di Jakarta Barat. Pengambilan sampel yang digunakan dalam penelitian ini adalah nonprobability sampling dengan metode purposive sampling dan akan membutuhkan 116 responden. Hanya sampel tertentu yang memenuhi kriteria dan dapat digunakan sebagai sampel. Untuk penelitian ini, program SPSS digunakan untuk mengetahui pengaruh semua variabel independen di atas terhadap variabel dependen. Metode statistik dalam penelitian ini adalah regresi berganda. Penelitian menunjukkan bahwa dari mulut ke mulut untuk citra merek, loyalitas merek, preferensi merek dan kepemimpinan merek pelanggan Miniso di Jakarta Barat.

Kata kunci: Brand image, brand loyalty, brand preference, brand leadership, word of mouth.

\section{PENDAHULUAN}

Industri ritel merupakan industri yang strategis dalam kontribusinya terhadap perkenomonian Indonesia. Dalam konteks global, potensi pasar ritel Indonesia tergolong yang cukup besar. Selain itu, dilihat dari sisi pengeluaran, GDP yang ditopang oleh pola konsumsi juga memiliki hubungan erat dengan industri ritel. Namun saat ini pertumbuhan bisnis ritel dan barang konsumsi di Indonesia sedang mengalami penurunan, daya beli masyarakat serta kondisi politik yang tidak stabil, menjadi salah satu faktor utama menurunnya sektor retail di Indonesia.

Melambatnya daya beli masyrakat sepanjang tahun lalu memberikan dampak penurunan pada sektor ritel. konsumsi masyarakat pada 2017 tumbuh 4,95\% lebih 
rendah dari tahun sebelumnya sebesar $5,01 \%$.

Terdapat empat emiten dalam sektor ritel yang telah mengeluarkan laporan keuangan tahun 2017 mengalami penurunan laba. Salah satu yang mengalami penurunan sepanjang tahun lalu adalah Hero Supermarket (HERO). Kerugian yang dialami mencapai $\mathrm{Rp} 191,4$ miliar dari tahun sebelumnya dan untung Rp 120.59 miliar. Tiga emiten lainnya yang mengalami penurunan dengan laba sebesar $5.6 \%$ adalah Matahari Departement Store (LPPF). Sedangkan Midi Utama Indonesia (Midi) mengalami penyusutan sebesar $48 \%$ serta Sumber Alfaria Trijaya (AMRT) mengalami penurunan saham hinggah $50 \%$. Melambatnya pertumbuhan penjualan yang diikuti dengan meningkatnya beban pendapatan membuat laba perusahaan ritel mengalami penurunan dibanding tahun lalu.

Pergerakan saham ritel sepanjang 2018 cukup beragam. Dari delapan emiten ritel dibawah ini, empat saham mencatat kenaikan dan empat sisanya mengalami penurunan. Menurunnya konsumsi masyarakat terjadi seiring melambatnya perekonomian domestik dan seiring dengan munculnya era belanja online yang secara tidak langsung membuat beberapa perusahaan ritel terpaksa harus menutup gerainya.

Ditengah terjadinya penurunan, Indonesia tetap masih bisa masuk pada 10 besar pada tahun 2017, pasar ritel Indonesia berada diposisi ke-8 dari 30 negara berkembang diseluruh dunia. Indonesia memperoleh skor $55,9 \%$ dari skor tertinggi 100 dan berada di urutan ke-8. Posisi ini turun dari tahun sebelumnya yang berada di urutan ke-5. Indonesia sudah lama menjadi incaran peritel asing. Peluang bagi investor asing untuk masuk ke pasar ritel domestik, baik unuk menguasai pasar swalayan maupun e-commerce.
Pada tahun 2017 peritel dari Jepang PT. Miniso life style tranding Jakarta mulai memasuki pasar Indonesia. Dengan menggunakan merek Miniso peritel Miniso memulai keagresifannya dalam memperluas pasarnya di Indonesia dalam waktu kurang dari satu tahun Miniso telah membuka 79 gerai yang tersebar di Indonesia.

PT. Miniso life style tranding Indonesia merupakan peritel yang berfokus kepada peralatan rumah tangga dan barang konsumsi dengan gerai ritel berbentuk 3 supermarket. Pada bulan Februari 2017, PT. Miniso life style tranding Indonesia membuka tiga toko pertamanya di Indonesia tepatnya di kota Jakarta yaitu di Mall Taman Anggrek, Lippo Mall Puri, dan Lippo Supermal Karawaci. Dengan mengusung modern layout serta visi untuk memenuhi gaya hidup yang berkualitas tinggi bagi masyarakat, PT. Miniso life style tranding Indonesia optimis bahwa dapat memberikan pilihan terbaik bagi masyarakat Indonesia, melalui word of mouth dari merek tersebut dapat membangun ekuitas merek, preferensi merek, loyalitas merek, kepemimpinan merek serta citra merek yang baik.

Dalam proses pembelian, sebelum memutuskan untuk menggunakan produk atau jasa, kebanyakan dari calon pembeli akan mencari informasi mengenai produk atau jasa tersebut terlebihi dahulu. Termasuk dalam membandingkan produk satu dengan produk lainnya, tidak sedikit melalui word of mouth atau lebih di kenal sebagai istilah WOM mereka mendapat informasi tersebut. Konsumen akan melakukan pencarian secara aktif melalui word of mouth mengenai hal-hal yang mereka butukan. Salah satu faktor yang mendukung keberhasilan dari PT. Miniso life style tranding Indonesia dalam memaksimalkan keunggulannya adalah melalui hubungan dari word of mouth. Sebagian besar bentuk komunikasi yang dilakukan oleh manusia adalah komunikasi 
dari mulut ke mulut (word of mouth). Proses ini digunakan untuk bertukar informasi, memberikan komentar maupun bentuk informasi lainnya.

Pada penelitian ini, peneliti memilih Merek Miniso sebagai obyek penelitian karena, ditengah terjadinya sektor ritel Indonesia yang saat ini sedang mengalami penurunan. Merek Miniso salah satu yang berhasil dalam memasuki sektor ini terbukti dari pembukaan 79 gerai dalam kurun kurang dari satu tahun. Melalui word of mouth yang dibangun dengan Brand image, Brand loyalty, Brand Preference serta Brand Leadership dibangun oleh Miniso.

\section{Word of Mouth}

Menurut Schiffman dan Winsenblit $(2015,134)$ word of mouth adalah salah satu bentuk informasi terkait pembelian yang paling kredibel karena konsumen tidak melihat pandangan orang lain tetapi lebih mempromosikan product yang memiliki tingkat kredibiltas yang tinggi. Sedangkan menurut Hasan $(2013,133)$ word of mouth adalah upaya seseorang untuk menyampaikan segala pesan bisnis kepada orang lain. Menurut Salomon $(2013,445)$ word of mouth adalah infromasi produk yang di dapat secara individual dari satu individual ke individual yang lain. Menurut

Keller $(2013,246)$ word of mouth adalah aspek kritis untuk membangun merek dimana konsumen berbagi pendapat mengenai suka, tidak suka dan pengalaman yang diterima antara satu merek dengan merek lainnya. Menurut Silverman $(2001,25)$ word of mouth adalah komunikasi mengenai produk dan jasa yang dibciarakan oleh orang-orang. Menurut Merriam, Webster (2013) Word of mouth adalah bentuk komunikasi secara lisan. Oleh karena itu penelitian ini menganggap bahwa word of mouth adalah konsumen memberikan informasi kepada konsumen yang lainnya dimana mereka merasa puas atau tidak puas terhadap produk dan menyebarkan informasi mengenai produk kepada orang lain.

\section{Brand Image}

Menurut Kotler dan Keller (2016, 330) bahwa Citra merek menggambarkan sifat ekstrinsik produk atau jasa, termasuk cara di mana merek berusaha memenuhi kebutuhan psikologis atau sosial pelanggan. Sedangkan menurut Chernev, Alex $(2015,22)$ citra merek adalah presepsi konsumen terhadap suatu merek, dimana semua asosiasi avokad termasuk dari citra merek yag partikular atau elemen merek lainnya seperti moto, karakter, tanda suara, produk desain dan kemasan.

Menurut Keegan (2011, 332) citra merek memiliki pengertian dari presepsi yang berasal dari refleksi merek dimana asosiasi merek tersebut dapat memberikan memori bagi konsumen.Sedangkan menurut Best et al, $(2007,346)$ citra merek mengacu pada memori skematik dari sebuah merek. Mengadung intepretasi target pasar dari produk atribut, manfaat, situasi pengguna, dan karakteristik pemasar manufaktur. Menurut Fandy Tjiptono (2005:49) citra merek memilki pengertian deskripsi tentang asosiasi dan keyakinan konsumen terhadap merek tertentu. Brand image itu sendiri memiliki arti kepada suatu pencitraan sebuah produk dibenak konsumen secara missal. Setiap orang akan memiliki pencitraan yang sama terhadap suatu merek. Menurut Sasmita dan Suki (2015) menyatakan bahwa citra merek adalah konstrak komplex yang bisa memberikan beberapa dimensi yang berbeda-beda. Menurut Jensen (2011) konsumen memakai citra merek untuk membuat presepsi umum dari produk yang pasti.

Jadi bisa disimpulan bahwa brand image merupakan proses asumsi dimana orang memilih, menilai dan mempunyai gambaran tersendiri tentang citra produk dalam benak konsumen melalui nilai dan kualitas yang tinggi. $\mathrm{H}_{1}$ Hubungan word of mouth terhadap brand image pelanggan merek Miniso di Jakarta Barat. 


\section{Brand Loyalty}

Menurut schiffman dan winsenblit $(2015,168)$ mendefiniskan bahwa brand loyalty diukur dari seberapa sering konsumen membeli merek tersebut baik mereka mengganti merek tersebut atau tidak, dan jika mereka melakukan hal tersebut seberapa sering mereka akan tetap terhadap komitmen pembelian merek secara teratur. Menurut Salomon $(2013,350)$ loyalitas merek menggambarkan bentuk pengahargaan dari perilaku pembelian yang memberikan refleksi kesadaran terhadap keputusan pembelian selanjutnya dari pembelian merek yang sejenis. Menurut Sopiah et al, $(2013,104)$ menjelaskan bahwa loyalitas lebih mengacu pada wujud perilaku dari unitunit pengambilan keputusan untuk melakukan pembelian secara terus-menerus terhadap barang atau jasa dari suatu perusahaan yang dipilih. Menurut salomon et al. $(2013,311)$ berpendapat brand loyalty adalah pencapaian terpenting dari kedua organisasi dan konsumen, untuk konsumen yang loyal dapat mencipatakan penghasilan generasi yang berkelanjutan dan untuk konsumen, loyalitas dapat memberikan penghargaan secara psikologis dan emosional. Menurut Clow and Baack $(2014,52)$ mendefinisikan bahwa loyaltias merek merupakan objectivias terakhir dalam membangun merek yang kuat. Loyalitas merek memberikan arti kosumen yang hanya membeli dan memakai satu merek saja.

Jadi dapat disimpulkan bahwa loyalitas merek merupakan sebuah bentuk kepuasan pelanggan terhadap suatu merek. Brand loyalty muncul saat konsumen hanya membeli satu merek saja dan melakukannya secara berulang-ulang.

$\mathrm{H}_{2}$ Hubungan word of mouth terhadap brand loyalty pelanggan merek Miniso di Jakarta Barat.

\section{Brand Preference}

Menurut Salomon (2013, 23) menyatakan bahwa brand preference merupakan bagian yang masuk dalam keputusan pembelian keputusan. Sedangkan menurut Clow dan Black $(2012,341)$ brand preference memilki seperangkat merek kecil yang paling sering dipilih. Menurut Kotler dan Keller $(2012,268)$ brand preference adalah produk atau jasa dimana konsumen bertemu dengan kebutuhan fungsional. Menurut Schiffman dan kanuk (2004:230) berpendapat bahwa loyalitas merek merupakan preferensi konsumen yang secara konsisten melakukan pembelian pada merek yang sama pada produk yang spesifik atau kategori pelayanan tertentu. Corte et al, (2010) menyatakan bahwa preferensi merek masih secara teratur yang dilaksanakan sama seperi simbol prediktor untuk setiap pembelian konsumen. Sedangkan Mitchel dan olsen (1986) menyebutkan bahwa preferensi merek merupkan kecenderungan terhadap suatu merek yang didasarkan pada kepercayaan pelanggan yang kuat pada saat tertentu.

Jadi dapat disimpulkan bahwa preferensi merek adalah preferensi yang dimilki seseorang terhadap suatu merek sehinggah dia lebih memilih untuk membeli atau menggunakan merek yang satu dibanding merek yang lain karena kebiasaan atau pengalaman yang dialaminya dimasa lalu.

$\mathrm{H}_{3}$ Hubungan word of mouth terhadap brand preference pelanggan merek Miniso Jakarta Barat.

\section{Brand Leadership}

Menurut Moote, Idris $(2013,128)$ Brand leadership adalah mengenai jangka panjang, dimana brand leaders mengerti bahwa membangun ekuitas merek membutuhkan waktu. Mereka mengetahui bahwa kesuksesan merek tidak dibangun hanya dengan satu produk yang dikeluarkan. Menurut Goldsmith and Hesselbein $(2008,166)$ brand leadership adalah sebuah indentitas dan reputasi dari para pemimpin diseluruh bagian sebuah perusahaan. Sedangkan menurut Aaker (1999) 
kepemimpinan merek dan pangsa pasar sebagai komponen penting dari ekutas merek. Menurut Miller and mills (2011) brand leadership diindentifikasikan sebagai asosiasi yang penting dalam satu set atribut merek karena pemimpin merek kemungkinan lebih memiliki nilai yang lebih, dan mereka selalu terlihat lebih sukses, memilki tujuan dan trend terbaru. Jadi dapat disimpulkan bahawa brand leadership adalah sebuah bentuk kepuasaan pelanggan terhadap suatu merek, dengan melakukan pembelian secara berulangulang. $\mathrm{H}_{4}$ Hubungan word of mouth terhadap brand leadership terhadap pelanggan merek Miniso di Jakarta Barat

\section{METODE PENELITIAN}

Penelitian ini dilakukan dengan tujuan untuk mengetahui apakah terdapat hubungan word of mouth terhadap brand image, brand loyalty, brand preference dan brand leadership pelanggan merek Miniso di Jakarta Barat. Rancangan penelitan yang akan digunakan adalah penelitian deskriptif dan kausalitas. Obyek dipenelitian ini adalah pelanggan dari merek Miniso di Jakarta barat. Yang terletak di tiga tempat yaitu Mall Taman Anggrek, Mall Central Park dan Mall Lippo Puri. Metode pengumpulan data dalam penelitian ini menggunakan kuesioner sebagai alat pengumpul dengan menggunakan data primer.
Responden dalam penelitian ini adalah pelanggan dari merek Miniso di Jakarta Barat yang memiliki kriteria yaitu Responden yang berjenis kelamin pria dan wanita, responden yang berdomisili di DKI Jakarta khususnya Jakarta Barat, responden yang membeli produk Miniso minimal dua kali dalam sebulan.

Jumlah sampel dalam penelitian ini adalah sebanyak 116 responden. Berpedoman dengan mengikuti ukuran sampel yang ditetapkan oleh Hair et al, (2014:100) yaitu penelitian yang pada umumnya memiliki faktor analisis tidak kurang dari 50 penelitian dan ukuran sampel harus 100 atau lebih besar.

Variabel penelitian ini terdiri dari word of mouth, brand image, brand loyaty, brand preference, brand leadership metode yang digunakan adalah skala likert. Menurut Sugiyono (2014:132) skala likert dapat digunakan untuk mengukur pendapat serta sikap dan presepsi seseorang atau sekelompok orang tentang fenomena sosial yang sedang terjadi. Responden yang akan menjawab pertanyaan dengan memilih salah satu jawaban dari 1-5 yaitu 1=Sangat Tidak Setuju, 2= Tidak Setuju, 3= Cukup Setuju, 4=Setuju, 5=Sangat Setuju.

\section{HASIL}

Berdasarkan hasil dari kuisoner, dapat disimpulkan responden adalah sebagai berikut:

\begin{tabular}{|l|l|l|}
\hline Keterangan & & Jumlah \\
\hline Jenis kelamin & Laki-laki & 36 \\
& Perempuan & 80 \\
\hline Usia & $<17$ tahun & 19 \\
& $18-22$ tahun & 50 \\
& $23-27$ tahun & 44 \\
& $28-32$ tahun & 3 \\
\hline Pendapatan & $<500.000$ & 25 \\
& $600.000-3000.000$ & 24 \\
& $3.100 .000-5.500 .000$ & 51 \\
& $>5.600 .000$ & 16 \\
\hline
\end{tabular}


Hasil Uji Kelayakan Suatu Model (Goodness fit of model). Pada model SEM, model pengukuran dan model struktural parameter diestimasi secara bersama-sama dan harus memenuhi tuntutan fit model, oleh karena itu model harus dilandasi teori yang kuat. Hasil estimasi dan fit model one step approach to SEM dengan menggunakan program aplikasi Amos 21 dapat dilihat di bawah ini:

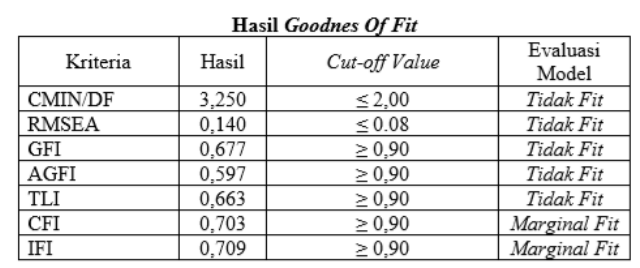

Tabel tersebut menunjukkan bahwa semua kriteria goodness of fit masih belum memenuhi cut off value.Dengan demikian model ini akan dilakukan modifikasi error sesuai dengan nilai

modification indices yang lebih besar dari 10 . Hasil Uji Goodnes Of Fit Setelah Dilakukan Modification Indices

Hasil Goodnes Of Fit Setelah Modification Indices
\begin{tabular}{|l|c|c|c|}
\hline \multicolumn{1}{|c|}{ Kriteria } & Hasil & Cut-off Value & $\begin{array}{c}\text { Evaluasi } \\
\text { Model }\end{array}$ \\
\hline CMIN/DF & 1,665 & $\leq 2,00$ & Good Fit \\
\hline RMSEA & 0,076 & $\leq 0.08$ & Good Fit \\
\hline GFI & 0,835 & $\geq 0,90$ & Marginal Fit \\
\hline AGFI & 0,767 & $\geq 0,90$ & Marginal Fit \\
\hline TLI & 0.900 & $\geq 0,90$ & Good Fit \\
\hline CFI & 0.923 & $\geq 0,90$ & Good Fit \\
\hline IFI & 0,925 & $\geq 0,90$ & Good Fit \\
\hline
\end{tabular}

menunjukkan bahwa sudah 5 kriteria goodness of fit telah memenuhi cut off value, hal tersebut bahwa hasil evaluasi menunjukkan model yang baik. Ini menjelaskan bahwa model yang digunakan dalam penelitian ini menghasilkan tingkat pendugaan yang diharapkan. Dengan demikian model ini adalah model yang baik dan layak untuk menjelaskan keterkaitan antar variabel dalam model.
Hasil Pengujian Hipotesis dan Hubungan Kausal. Berikut merupakan hasil pengujian hipotesis setelah sebagian besar kriteria goodness of fit terpenuhi. Dengan demikian besaran koefisien masing-masing faktor lebih dapat dipercaya sebagaimana terlihat pada uji kausalitas pada tabel berikut.

Pengujian Hipotesis
\begin{tabular}{|c|c|c|c|c|}
\hline Hubungan & Estimate & C.R. & P & Keterangan \\
\hline Word of Mouth $\rightarrow$ Brand Image & 0,167 & 1,967 & 0,049 & Signifikan \\
\hline Word of Mouth $\rightarrow$ Brand Loyalty & 0,798 & 5,694 & 0,000 & Signifikan \\
\hline Word of Mouth $\rightarrow$ Brand Preference & 0,638 & 4,429 & 0,000 & Signifikan \\
\hline $\begin{array}{c}\text { Word of Mouth } \rightarrow \text { Brand } \\
\text { Leadership }\end{array}$ & 0,609 & 5,543 & 0,000 & Signifikan \\
\hline
\end{tabular}

Pengujian Hipotesis diperoleh dari nilai estimate yang dihasilkan bernilai positif yakni sebesar 0.167 degan probabilitas sebesar 0.049 . Dimana nilai probabilitas lebih kecil dari $a=5 \%$ atau 0.05 . sehinggah dapat disimpulkan bahwa $\mathrm{H} 01$ ditolak dimana word of mouth memiliki hubungan yang signifikan dan positif terhadap brand image.

Pengujian Hipotesis kedua diperoleh dari nilai estimate yang dihasilkan bernilai positif yakni sebesar 0.798 degan probabilitas sebesar 0.000 . Dimana nilai probabilitas lebih kecil dari $\alpha=5 \%$ atau 0.05 . sehinggah dapat disimpulkan bahwa $\mathrm{H} 02$ ditolak dimana word of 
mouth memiliki hubungan yang signifikan dan positif terhadap brand loyalty.

Pengujian Hipotesis ketiga diperoleh dari nilai estimate yang dihasilkan bernilai positif yakni sebesar 0.638 degan probabilitas sebesar 0.000 . Dimana nilai probabilitas lebih kecil dari $\alpha=5 \%$ atau 0.05 . sehinggah dapat disimpulkan bahwa $\mathrm{HO}$ ditolak dimana word of mouth memiliki hubungan yang signifikan dan positif terhadap brand preference.

Pengujian Hipotesis keempat diperoleh dari nilai estimate yang dihasilkan bernilai positif yakni sebesar 0.609 degan probabilitas sebesar 0.000 . Dimana nilai probabilitas lebih kecil dari $\alpha=5 \%$ atau 0.05 . sehinggah dapat disimpulkan bahwa HO4 ditolak dimana word of mouth memiliki hubungan yang signifikan dan positif terhadap brand leadership.

\section{PENUTUP}

Berdasarkan penelitian yang dilakukan dapat disimpulkan bahwa: (1) memiliki hubungan yang signifikan word of mouth terhadap brand image pelanggan merek Miniso di Jakarta Barat. (2) memiliki hubungan yang signifikan word of mouth terhadap brand loyalty pelanggan merek Miniso di Jakarta Barat. (3) memiliki hubungan yang signifikan word of mouth terhadap brand preference pelanggan merek Miniso di Jakarta Barat. (4) memiliki hubungan yang signifikan word of mouth terhadap brand leadership pelanggan merek Miniso di Jakarta Barat. Penelitian ini telah dilakukan sesuai prosedur ilmiah, namun masih memiliki beberapa keterbatasan yaitu : terbatasnya variabel independen pada penelitian, dimana penelitian ini peneliti hanya menggunakan variabel word of mouth Selain itu dalam penelitan ini, data yang dianalisis menggunakan instrumen yang didasarkan pada presepsi jawaban responden. Hal ini dapat mengakibatkan masalah jika responden berbeda-beda. Responden yang digunakan dalam penelitian ini adalah responden yang sudah membeli produk miniso sebanyak dua kali. Selain itu mengingat keterbatasan waktu, biaya dan tenaga maka penelitian ini hanya terbatas pada ruang lingkup pelanggan merek Miniso di Jakarta Barat. Keterbatasan waktu dan biaya sehinggah penelitian ini menggunakan 116 responden dimana 116 responden tersebut dianggap telah mewakili suatu populasi. Berdasarkan penelitian yang telah dilakukan, peneliti mengajukan beberapa saran bagi peneliti selanjutnya, disarankan bagi peneliti selanjutnya mengajukan penambahan variabel independen seperti customer satisfaction, service quality. Selain itu peneliti selanjutnya di sarankan sebaiknya menggunakan sampel yang lebih banyak lagi agar sampel yang diambil dapat mewakili populasi dengan lebih baik. Disarankan juga bagi peneliti selanjutnya untuk menggunakan obyek penelitian dengan kategori yang berbeda.

\section{REFERENCES:}

Aaker, D.A. and Joachimsthaler, E. 1999 The lure of global branding. Harvard Business Review (NovemberDecember) 135-144.

Clow, K. E., \& Baack, D. 2016. Integrated Adverstising, Promotion, and Marketing Communication Seventh Edition. Pearson Education Limited.

Godes, D., Mayzlin, D., Chen, Y., Das, S., Dellarocas, C., Pfeiffer, B., \& Verlegh, P. 2005. The firm's management of social interactions. Marketing Letters, 16(3-4), 415-428. Goyette

Hasan, Ali 2013 , Marketing dan Kasus Kasus Pilihan, PT. Buku Seru ,Jakarta .

Hogan, J. E., Lemon, K. N., \& Libai, B. 2004. Quantifying the ripple: Word-ofmouth and advertising effectiveness. Journal of Advertising Research, 44(3), 271-280.

J. Keegan, Warren, and C. Green, Mark. 2011. Global Marketing 7th Edition. New Jersey: Pearson Prentice Hall. 
Kearney, A.T. 2017. Indonesia Masuk daftar 10 Pasar Ritel Teraktif. Katadata Indonesia.Diambil dari : http://databoks.katadata.co.id/datapublish/2017/06/06/indoneiamasukdaftar-10-pasarritelaktif.(akses:17september 2017)

Kotler, P., Keller, K. L., Ancarani, F., \& Costabile, M. 2014. Marketing management (14th edition). Pearson

Kotler, Philip, and Kevin Lane Keller .2012. Marketing Management. New Jersey: Pearson Prentice Hall.

Merriam-Webster 2013, "Word of mouth", available at: www.merriamwebster.com/dictionary/word-of-mouth (accessed22November2013).

Miller, K.W. and Mills, M.K. 2011, "Contributing clarity by examining brand luxury in the fashion market", Journal of Business Research, Vol. 65 No. 10, pp. 1471-1479

Moote, Idris., 2013. Sixty Minute Brand Strategist: The Essential Brand Book for Marketing Professionals Chernev, Alexander. 2015. Strategic Brand Management First Edition. Cerebellum Press Limited.

Salomon, M. R. 2015. Consumer Behaviour Eleventh Edition. Pearson Education Limited.

Schiffman, L. G.,\& Wisenblit, J. L. 2015. Consumer Behaviour Eleventh Edition Pearson Education Limited

Sekaran, U \& Bougie, R. 2013. Research methods for business: A skill building approach. 5 th Edition. UK: John Willey \& Sons, Ltd.

Solomon, M. 2013, Consumer Behavior: Buying, Having, and Being, PrenticeHall, Upper-Saddle, NJ.

Sugiyono. 2007. Memahami Penelitian Kualitatif. Bandung: Alfabeta

Taylor, G.A. 2001, "Coupon response in services", Journal of Retailing, Vol. 77 No. 1, pp. 139-151.

Yamin, Sofyan dan Heri Kurniawan. 2009. Structural Equation Modeling: Belajar Lebih Mudah Teknik Analisis Data Kuisioner dengan Lisrel-PLS. Jakarta : Salemba infotek. 